H. В. Ким. Дискурсивный анализ поэтического текста русского эмигрантского поэта Льва Гроссе

Научная статья

УДК 82

DOI: $10.18101 / 2686-7095-2021-1-61-69$

\title{
ДИСКУРСИВНЫЙ АНАЛИЗ ПОЭТИЧЕСКОГО ТЕКСТА РУССКОГО ЭМИГРАНТСКОГО ПОЭТА ЛЬВА ГРОССЕ
}

\author{
(C) Ким Наталья Владимировна \\ соискатель кафедры китайского языка, \\ Забайкальский государственный университет \\ Россия, 672039, г. Чита, ул. Александро-Заводская, 30 \\ natkim_4768@mail.ru
}

Аннотация. В статье анализируется дискурс поэтического текста «Ты — юная, ты стройная, как ель» малоизвестного в России поэта восточной ветви русской эмиграции Льва Гроссе с использованием разных общефилологических методов исследования. Актуальность темы обусловлена необходимостью знакомства российского читателя с литературой русских эмигрантов «первой волны» в Китае, так как несмотря на большое количество исследований литературное наследие данного направления русской эмиграции не стало еще настоящей частью нашей культуры. Автором рассматривается тема-рематическая организация текста. Когезия и когерентность произведения достигаются использованием богатого ресурса поэтического дискурса, включая стилистические фигуры - метафору, эпитеты, антитезу, повторы, а также культурные концепты. Своеобразие размера, синтаксиса, параллелизм 1-й и 2-й строк, торжественная поэтическая дикция - все это помогает раскрыть авторскую интенцию. Описываются факты биографии автора как определяющие моменты творчества. Утверждается, что подобная интерпретация может привлечь к поэтическому наследию Л. Гроссе новых читателей и исследователей.

Ключевые слова: дискурс; тема; рема; когезия; когерентность; культурный код; пресуппозиция; интертекстуальность; концепт.

\section{Для цитирования}

Ким Н. В. Дискурсивный анализ поэтического текста русского эмигрантского поэта Льва Гроссе // Вестник Бурятского государственного университета. Филология. 2021. Вып. 1. С. 61-69.

Изучение дискурса - коммуникативно-событийной среды, в которой зарождается замысел и формируется текст, продукт дискурса, выход за рамки смыслового содержания текста, привлечение в сферу исследования художественного опыта всех участников дискурсивной деятельности (автор, читатель, персонажи и т. п.) - все это очень важно сегодня, потому что «текст: а) существует в тесной связи с действительностью; б) имплицитно и эксплицитно связан с другими текстами, образуя интертекстуальность; в) взаимодействует с воспринимающим сознанием читателя, которое не только осуществляет понимание его смыслового содержания, но и создает свой собственный воображаемый объект; г) существует в нашем сознании на своеобразном интерпретационном фоне, где не только разъясняются завуалированные фрагменты его содержания, но и выявляются неявные, скрытые смыслы» [1, с. 7]. О необходимости анализирования художественных текстов с точки зрения «динамической природы их производства и понимания» 
предлагал еще в 70-е гг. прошлого столетия голландский лингвист Т. А. ван Дейк, один из пионеров теории текста, теории речевых актов и анализа дискурса.

Поэтический язык, который является лингвальной основой поэтического дискурса, был описан многими известными отечественными лингвистами прошлого столетия и современными российскими исследователями. Можно только перечислить такие работы, как «Поэтика и действительность. Из наблюдений над зарубежной литературой $\mathrm{XX}$ века» В. Г. Адмони, «Поэтический язык как предмет поэзии» М. М. Бахтина, «Язык поэзии и язык прозы» А. Н. Веселовского, «Поэтика и ее отношение к лингвистике и теории литературы» В. В. Виноградова, «Филологические исследования: лингвистика и поэтика» Г. О. Винокура, «Текст как объект лингвистического исследования» И. Р. Гальперина, «О русской поэзии» М. Л. Гаспарова, «Теория литературы. Поэтика. Стилистика» В. Н. Жирмунского, «Языковые ключи» В. И. Карасика, «Принцип историзма в изучении содержания и формы литературного произведения» Д. С. Лихачева, «Анализ поэтического текста. Структура стиха» Ю. М. Лотмана, «Семантическое пространство поэтического дискурса» Н. В. Монгилевой, «Проблема стихотворного языка» Ю. Н. Тынянова, «Дискурсивное пространство поэтического текста: образное слово в русской лирике конца XVII-XXI веков» И. И. Чумак-Жунь, «Опыт лингвистического толкования стихотворений» Л. В. Щербы, «Поэзия и проза» Б. М. Эйхенбаума, «Лингвистика и поэтика» Р. О. Якобсона. В них определялся статус поэтического языка, исследовались его ключевые элементы и качества на всех уровнях - метрическом, фонетическом, лексическом, грамматическом, синтаксическом, выявлялась специфика лингвистического анализа поэтического текста и т. д.

«С позиций дискурсивного осмысления поэзия представляет собой общение особого рода, насыщенное глубинными эмоциональными переживаниями и выражаемое в эстетически маркированных знаках» [2, с. 326]. Поэтический текст благодаря образности смыслов более ассоциативен и информативен, поэтому поэтические образы закрепляются в памяти читателя, предлагая возможность множественных интерпретаций.

Поэтический текст «Ты - юная, ты - стройная, как ель...» принадлежит перу малоизвестного русского поэта восточной ветви эмиграции Льва Гроссе. Стихотворение можно отнести к разновидности гражданского жанра в поэзии, патриотической лирике, так как все пропитано невероятной любовью автора к Родине:

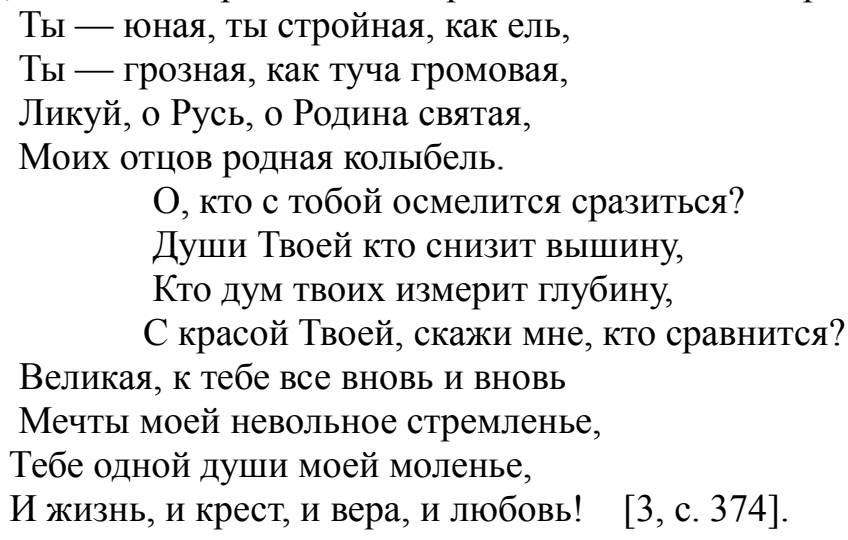


H. В. Ким. Дискурсивный анализ поэтического текста русского эмигрантского поэта Льва Гроссе

Лев Викторович Гроссе - сын Виктора Федоровича Гроссе (1869-1931), дворянина, блестящего русского дипломата, последнего императорского консула России в Шанхае (1911-1920). Л. В. Гроссе родился 15 июня 1906 г. в Йокогаме, окончил гимназию в Китае, изучал в Сорбонне и Берлине философию, филологию, бактериологию. Однако он так любил Россию - «отцов родную кольбель», которую видел в детстве очень короткое время, так стремилось его «бездомное сердце» попасть в атмосферу родного языка, что в 1948 г. репатриировался в СССР, потеряв к тому моменту мать, отца и одну из двух старших сестер. Он жил и работал в Казани, где через год был арестован. Ходили слухи в эмигрантских кругах, что произошло это по наводке одной из бывших жен. Его переводили из одной тюрьмы в другую, умер Лев Гроссе предположительно в Бутырской тюрьме мучительной смертью после долгих пыток электричеством (по словам В. П. Жобер, племянницы его бывшей жены Н. И. Ильиной), дата его смерти точно не известна, только год - 1950. Так сгинули тысячи вернувшихся из Китая на родину эмигрантов, большинство из которых автоматически причислялись к японским шпионам только по факту проживания и работы во времена японской оккупации в Маньчжурии.

Л. Гроссе с детства имел слабое здоровье и при этом всегда много работал, в том числе переводчиком в иностранных фирмах, в Шанхайском отделении ТАСС, был помощником управляющего кинематографа «Азия» и даже пел в русских ресторанах. Был дважды коротко женат, на Н. И. Ильиной и М. А. Болт, детей не было. Очень много писал, в 23 года уже был признан за свой «легкий стих», за «незаурядную прозрачность стихотворного узора», за тонкий поэтический слух серьезным поэтом. Много печатался в Европе, США, Китае. Учась во Франции, сотрудничал в газете монархистов «Возрождение», где в те годы редактором был известный русский политик, экономист, философ, историк и издатель П. Б. Струве. Там же познакомился с еще одним знаменитым эмигрантом - философом Н. А. Бердяевым, с которым потом состоял в двадцатилетней переписке. Л. Гроссе был членом «Шанхайской Чураевки» и «Цеха поэтов», редактором журнала «Муза», первым начал печататься в Шанхае. Сначала отдельными изданиями выходили одна за другой его поэмы «Ведение», «Пророк», «Грехопадение», «Кремль», «Песня жизни», «Альфа-омега. Завет полей», затем с 1929 по 1939 г. вышло 6 сборников стихов, в 1941 г. вышла книга, прославляющая советский народ, посвященная борьбе СССР с фашистами.

Адресация мысли поэтов к Родине, к России - это не только давняя традиция русских поэтов, а в условиях эмиграции это еще и очень интимная, больная, эмоциональная тема, обусловленная и мотивированная самой жизнью эмигрантов, историческими обстоятельствами революционной и послереволюционной эпох, всеми пережитыми потерями, разлукой с Отчизной, бесконечной любовью к ней, горькими раздумьями о ее судьбах, мечтой о встрече с ней, национальной культурой и т. д. Апелляцию к родине у поэтов Серебряного века, литературные традиции, эстетику этого периода в истории русской поэзии переняли и сохранили представители эмигрантской русской литературы, сдвинув тем самым, по нашему мнению, хронологические рамки Серебряного века на десятилетия вперед, хотя исследователи связывают его конец то со смертью А. Блока и расстрелом Н. Гумилева, то с самоубийством В. Маяковского. 
Образ родной страны явлен и отражен в эмигрантской поэзии в таких базовых метафорах, как родина - «отчий дом», «родимый, любимый, далекий, снежный, отчий край», «семья родная», «детьми замученная мать», «отцов родная колыбель», «парус родной», «крест, вера, любовь», «родина - моя мечта», «моя печаль», «расколотая душа», «утерянная скиния», «добрый улей», «вестница чудес», «светоч и счастье», «Государыня», «замученная Императрица», «...вы же женщина - о Родина!» и многих других.

Обобщенная макротема (МТ) текста данного поэтического произведения $T b l$, Родина - дана не сразу, она разорвана. В 1-й строке есть только $T b l$, апелляция к Родине, читатель видит слово Родина только в 3-й строке. По преимуществу местоимение 2-го лица единственного числа (Ты) выполняет функцию адресации автора: это может быть реальный собеседник в диалогах в художественной прозе или просто в коммуникативном акте. Поэзия тоже очень часто использует это местоимение, однако в поэтических текстах адресат зачастую отдален в пространстве и во времени от говорящего. Поэт может обращаться к любимому человеку, иным лицам, к неодушевленному предмету, к географическим реалиям - топонимам во внутреннем монологе, в акте автокоммуникации - к самому себе. В данном случае Л. Гроссе адресует свои мысли родной стране и тем самым подтверждает близость своего произведения поэзии Серебряного века: «Очень важный адрес апелляций поэта, мотивированный жизнью автора, его самосознанием, эпохой, историческим временем, системой национальных традиций и т. д. Это адресация к родной стране, к Руси, к России. Например, у поэтов Серебряного века читаем: “Ты и во сне необычайна. Твоей одежды не коснусь ... и в тайне - ты почиешь, Русь” (1906) - А. Блок; “Ой ты, Русь, моя родина кроткая...” (1914) - С. Есенин; "И ты, огневая стихия... Россия, Россия, Россия — Мессия грядущего дня!” (1917) - А. Белый» [4, с. 111].

В анализируемом тексте обращение автора к Родине местоимением 2-го лица единственного числа с прописной (большой) буквы $-T b l-$ несет информацию о семантике любимой страны. $T b l$ с большой буквы связано с категорией вежливости, близких отношений и маркирует сокращение дистанции между говорящим и адресатом (Родиной) - референтом данного местоимения, категория лица здесь понимается и коммуникативно.

Макротема-1 по веерному типу расчленяется, группируя ряд конкретизирующих микротем - mы (мт-1), Русь (мт-2), кольбель (мт-3), Великая (мт-4), тебе (мт-5) и микрорем - «юная, стройная, грозная» (мр-1), «ликуй» (мр-2), «моих отиов» (мр-3), «мечты моей стремленье» (мр-4), «души моей моленье», «и жизнь, и крест, и вера, и любовь» (мр-5). Но стабильной макротему трудно назвать, т. к. в середине стихотворения, с 5-й по 8-ю строку, появляется вторая, автономная, макротема (МТ-2), выраженная повторяющимся вопросительным местоимением кто (4 раза), с разными ремами - осмелится сразиться (1), снизит вышину (2), измерит глубину (3), сравнится (4). Однако в этой строфе благодаря местоименным повторам - тобой, твоей, твоих - не прерывается и актуализация MT-1 (Tbl, Родина). Эти местоимения пронизывают весь текст стихотворения, поэтому здесь мы видим прогрессию со сквозной темой.

Необходимо отметить, что во второй строфе при помощи вопросительного местоимения кто (МТ-2) формируются риторические вопросительные предложения, которые подразумевают ответ с отрицательными местоимениями: Кто осмелит- 
H. В. Ким. Дискурсивный анализ поэтического текста русского эмигрантского поэта Льва Гроссе

ся...? - Никто не осмелится...; К Кто снизит...? - Никто не снизит...; Кто измерит...? - Никто дум твоих не измерит... и Кто сравнится...? - Никто с красой твоей не сравнится. Происходит как бы полное устранение объекта кто. Применение местоимений разных разрядов имеет широкие возможности, о чем писали лингвисты В. В. Виноградов, Е. М. Вольф, И. И. Ковтунова, С. М. Кузьмина, Т. М. Николаева. А. М. Пешковский, О. Н. Селиверстова и другие. Свойства местоимений обозначить опосредованно объект, завуалировать его, создать атмосферу таинственности, эстетической неопределенности дают благодатный материал для языковой игры и в конечном счете в стремлении поэтического языка передать тончайшие движения души автора. В 12 строках стихотворения Льва Гроссе мы встречаем 17 местоимений.

Во второй строфе используется «интеррогативный (изобличающий, в данном случае - в хорошем смысле) критерий» выделения пресуппозиции, согласно которому то, что подразумевается в ответе-предложении, является предметом вопроса, т. е. то, о чем спрашивается в вопросе. Пресуппозиция остается неизменной, истинной. Говорящий (автор) как бы представляет степень предварительного знания и осведомленности адресата (читателя) о величии, силе, красе, душевности и духовности России как о само собой разумеющимися.

Позиция лирического героя стихотворения - поэта — явно выражена при помощи притяжательных местоимений моих, моей (повторенного дважды) и личного местоимения 1-го лица единственного числа в дательном падеже - мне. Своеобразный синтаксис, знаки пунктуации (два вопросительных и восклицательный в конце) показывают эмоциональную тональность размышлений поэта, а выбор лексики и ее особая организация на всех уровнях подчинены интенции автора.

Коннекторным рядом макротемы, выраженным в точных повторах личных и притяжательных местоимений ты (3), тебе (2), моей (2), твоей (2), парадигматическим повтором этой же лексики, связывается текст в одно целое, достигается когезия, грамматическая и лексическая связность - одна из определяющих характеристик текста. При этом тавтологии нет, зато усиливается эмоциональное и экспрессивное напряжение в тексте, все внимание читателя сосредоточено на одном объекте - Родине. Когерентность, смысловое единство текста стихотворения обеспечивается художественно-ассоциативной логикой поэта, всей темарематической структурой произведения.

Микроремы рисуют образ любимой родины, которая далеко, обращение к ней автора в форме личного местоимения единственного числа раскрывает очень близкий, сугубо интимный, трепетный, нежный характер отношения автора к почти не известной, но такой любимой Родине. Эмоциональное обращение к Отчизне с христианских позиций вызывает эпитет святая, а значит, «духовная, нравственно-непорочная, чистая... божественная, небесная» (В. И. Даль) и такие коммуникативно значимые компоненты стихотворения, как эстетическая метафора «души ... моленье» и слова с отвлеченной семантикой «...и крест, и вера...», которые граничат с категорией определенности, так как под «крестом» каждый христианин понимает «жизнь, судьбу, все, что выпадает на жизненном пути», а под «верой» — «добровольное согласие на принятие Богооткровенной Истины».

В свое время А. Вежбицкая назвала сепировское утверждение «лексика очень чувствительный показатель культуры народа» настоящим «прозрением» и доказывала своими трудами, что через ключевые слова любого языка можно по- 
нять культуру данной нации. Она рассматривала некоторые русские непереводимые культурно значимые концепты, такие как «истина», «душа» и т. д. «Душа ...духовное, моральное и эмоциональное ядро человека и некий внутренний театр, в котором развертывается его моральная и эмоциональная жизнь» [5, с. 17].

О душе России, о русской душе писали очень многие, она является главным героем многих поэтических произведений, философских строк, написанных на русском языке и в эмиграции. Так, еще один эмигрант - религиозный и политический философ Н. А. Бердяев, с которым долгие годы Л. Гроссе переписывался, создал целый труд «Душа России» (1915), где пишет, что тайна сия непостижима, настолько душа России противоречива, мятежна в своем постоянном искании правды, в вечной печали о горе и страдании народа и всего мира, и приводит слова Тютчева «Умом Россию не понять...».

Обращение к душе в поэтических текстах - один из ключевых моментов русской поэзии, эмигрантская поэзия - не исключение. Лингвоспецифичный концепт «душа», наряду с Родиной, Россией, Богом, Иисусом Христом, Богородиией, любовью, верой, надеждой, судьбой, жизнью, разлукой, ненавистью, смертью, кровью, тоской, печалью, мечтой, домом, памятью, войной, борьбой, врагами, молитвой, православным храмом, иконой, счастьем, изгнанием, бегством, сиротством, слезами и другими, составляющими концептосферу творчества многих эмигрантских поэтов, является одним из самых частотных. В таких произведениях, как «Шум парка душу мне тревожит», «Я в жертву жизни душу приносила», «Надо душу подальше укрыть» О. Скопиченко, «Моя душа на цыпочках...» А. Несмелова, «Опять в полях я и душа нагая» Е. Яшнова, «Смятенная душа не знает слов» Л. Хаиндровой, «Душа научилась беречь» О. Тельтофт, «Россия» М. Волина, «Святая Русь... навек душа моя» Ф. Камышнюка и многих других, душа глядит на мир, кочует, летает, печалится, плачет, тоскует, грустит,, болит, страдает, устает, тянется к любви, любит, звенит, поет, волнуется, может расплескаться, учится, ненавидит, каменеет, благодарит, радуется, не может насытиться, соблазняется, негодует, просветляется.... У Л. Гроссе она молится. «Локусом молитвы является внутренний мир человека, душа» [6, с. 268].

«Слово душа широко используется не только в религиозных контекстах душа понимается как средоточие внутренней жизни человека, как самая важная часть человеческого существа» [7, с. 30]. Использование метафор «Тебе одной души моей моленье!», "Души твоей кто снизит вышину? раскрывает философский взгляд, глубокое религиозное сознание поэта. Вере в Бога (в семье Гроссе все были лютеранами) посвящены многие стихи поэта: «Путь», «Господь», «Георгий Победоносец», «Два храма» и другие. Вот несколько сильных строк из его произведения «Путь»:

$$
\begin{aligned}
& \text { Я - человек, я - царь, я создан Богом, } \\
& \text { Я ведаю, что жизнь в руках Его, } \\
& \text { И голос мой в своем порыве строгом } \\
& \text { Без вышних сил не значит ничего ... }
\end{aligned}
$$

Эмигрантская бесприютность, экзистенциальное одиночество, отсутствие связи с Россией при бесконечной любви к ней приводят Л. Гроссе к осознанию одухотворенной, живой души Родины, отщов родной кольбели, куда стремятся вернуться большинство эмигрантов. В этом маленьком послании к Отчизне, к 
H. В. Ким. Дискурсивный анализ поэтического текста русского эмигрантского поэта Льва Гроссе

святой Руси преобладает женское начало, здесь все существительные женского рода, кроме креста и отизов, и это придает стихотворению особый лиризм, как будто поэт признается в любви любимой женщине.

Л. Гроссе прибегает еще к одной стилистической фигуре - антитезе, которая выполняет функцию усиления выразительности, яркости образа России и позволяет читателю глубже понять авторскую интенцию. Родина у Л. Гроссе и «юная, стройная», и «грозная», то он сравнивает ее с елью, то с тучей грозовой, то говорит о вышине души, то о глубине дум.

Удивляет безмерная сила чувств Л. Гроссе к России, которая является его родиной только по корням, по предкам, ведь он, сын дипломата, родился в другой стране, в Японии и Китае рос, в европейских странах учился, а погиб после тюремных пыток в стране, где был в детстве считанные месяцы, но куда стремился всей душой, которую боготворил. После прочтения его произведений понимаешь, как велики были его знания истории и культуры России, какое глубокое христианское мировосприятие ему, его брату и сестрам, тоже родившимся и выросшим за границей в силу семейных обстоятельств, было вложено и передано любящими родину родителями.

Н. А. Бердяев в книге «Смысл творчества» (1916), говоря о том, что человек, его тело и дух находятся в плену у этого мира, утверждал, что лишь благодаря творчеству можно освободиться. «Тайна творчества есть тайна свободы» [8, c. 369]. Этим и жили талантливые люди в эмиграции. Поэзия в частности, да и писательство в целом спасали эмигрантов, писали многие и даже те, кто раньше и не думал браться за перо. «Странная это вещь - в годы всеобщей разрухи и переживаемых тягот множество людей, в особенности молодежь, тянулось к поэзии, находя в ней живительную замену хлебу насущному» [9, с. 67].

Л. Гроссе воспитан на русской классической литературе, впитал дух национальной поэзии и является достойным почитателем и продолжателем ее традиций. Показателен тот факт, что поэтический текст «Ты - юная, ты - стройная...» заканчивается неполным заимствованием из великого А. С. Пушкина «И жизнь, и крест, и вера, и любовь!», своеобразной реминисценцией, рассчитанной на ассоциации читателя. Поэт использует интертекстуальность, заимствует у классика два слова (и жизнь... и любовь), рифму (вновь - любовь) и синтаксическую структуру последней строки из «Я помню чудное мгновенье», посвященного А. П. Керн.

Творчество Л. Гроссе в России почти не известно, книги его не переиздавались. Они хранятся только в частных коллекциях, в единственных экземплярах в нескольких российских библиотеках, в русской эмигрантской коллекции собрания Библиотеки им. Гамильтона Гавайского университета в Гонолулу, где работает признанный в научном мире специалист по русской литературе 1-й волны эмигрантов в странах Азиатско-Тихоокеанского региона, библиограф, коллекционер Патриция Полански. А также в Хабаровском краевом музее им. Н. И. Гродекова, во второй книге «Паровозы гудят у Цицикара» 10-томника «Литература русских эмигрантов в Китае», собранного и изданного в 2005 г. в Пекине благодаря усилиям профессора Цицикарского университета, большого знатока русского языка и друга нашей страны Ли Янлена (он сам пишет стихи на русском языке и является членом Союза писателей России). 
Ввести поэзию Л. Гроссе в контекст русской классической литературы, несомненно, поможет обогатить представление о русской эмигрантской поэзии, даст читателю понимание еще одного поэтического мира с позиции понимания его языка.

\section{Литература}

1. Текст дискурс / Н. Ф. Алефиренко, М. А. Голованева, Е. Г. Озерова, И. И. ЧумакЖунь. Москва: ФЛИНТА, Наука, 2012. 232 с. Текст: непосредственный.

2. Карасик В. И. Языковые ключи. Москва: Гнозис, 2009. 406 с. Текст: непосредственный.

3. Гроссе Л. В. Ты - юная, ты - стройная, как ель // Литература русских эмигрантов в Китае. Паровозы гудят у Цицикара: в 10 т. / составитель Ли Янлен. Пекин: Китайская молодежь, 2005. Т. 2. 709 с. Текст: непосредственный.

4. Папина А. Ф. Текст: его единицы и глобальные категории. Москва: УРСС, 2002. 368 с. Текст: непосредственный.

5. Вежбицкая А. Понимание культур через посредство ключевых слов. Москва: Языки славянской культуры, 2001. 290 с. Текст: непосредственный.

6. Карасик В. И. Языковой круг: личность, концепты, дискурс. Москва: Гнозис, 2004. 447 с. Текст: непосредственный.

7. Зализняк А. А., Левонтина И. Б., Шмелев А. Д. Ключевые идеи русской языковой картины мира: сборник статей. Москва: Языки славянской культуры, 2005. 554 с. Текст: непосредственный.

8. Бердяев Н. А. Смысл творчества // Философия свободы. Москва, 1989. 607 с. Текст: непосредственный.

9. Слободчиков В. А. Воспоминания / Русский Харбин / составление, предисловие и комментарии Е. П. Таскиной [2-е изд., испр. и доп.]. Москва: Изд-во МГУ: Наука, 2005. 349 с. Текст: непосредственный.

Статья поступила в редакцию 24.11.2020; одобрена после рецензирования 28.01.2021; принята к публикации 25.03.2021.

\section{DISCOURSIVE ANALYSIS \\ OF POETICAL TEXT BY RUSSIAN EMIGRANT POET \\ IN CHINA LEV GROSSE}

Natalya V. Kim

Applicant of Chinese Language Department,

Trans-Baikal State University

30 Aleksandro-Zavodskaya St., Chita 672039, Russia

natkim_4768@mail.ru

Abstract. The article reviews the discourse of the poetic text "You are young, you are slender as a fir" by Lev Grosse, a poet of the eastern branch of the Russian emigration, little known in Russia. The article author uses various general philological and linguistic research methods. The relevance of the topic is due to the need to introduce Russian reader with the literature of Russian emigrants of the "first wave" in China; despite a large number of studies, the literary heritage of this branch of Russian emigration has not yet become a part of Russian culture. The author reviews the theme-rhematic structure of the text. The cohesion and coherence of the text is achieved by using rich resources of poetic discourse, including stylistic figures - metaphor, epithets, antithesis, various kinds of repetitions, cultural con- 
H. В. Ким. Дискурсивный анализ поэтического текста русского эмигрантского поэта Льва Гроссе

cepts. The originality of size, syntax, parallelism of the first and second lines, solemn poetic diction - all this helps reveal the author's intention. The facts of the author's biography are described as defining moments of his work. Such interpretation can attract new readers and researchers to Lev Grosse's poetic heritage.

Keywords: discourse; theme; rhema; cohesion; coherence; cultural code; presupposition; intertextuality; concept.

For citation

Kim N. V. Discoursive Analysis of Poetical Text by Russian Emigrant Poet in China Lev Grosse. Bulletin of Buryat State University. Philology. 2021; 1: 61-69 (In Russ.).

The article was submitted 24.11.2020; approved after reviewing 28.01.2021; accepted for publication 25.03.2021. 